\title{
KONSEP DASAR DALAM MEMPELAJARI MATA KULIAH ALGORITMA \\ PEMRO GRAMAN
}

Leli Setiani (0305202125)

Program Studi Pendidikan Matematika

Fakultas Ilmu Tarbiyah dan Keguruan UIN Sumatera Utara Jl. William Iskandar

Pasar V, Medan Estate

\begin{abstract}
ABSTRAK
Algoritma mempunyai serangkaian langkah buat membongkar permasalahan. Langkahlangkahnya disusun secara sistematis. Algoritma merupakan langkah- langkah buat menyusunkan langkah- langkah terintegrasi, serta penggunaannya buat membongkar permasalahan mempunyai metode spesial buat menuntaskan permasalahan nyata( WebsterDictionary). Tujuan dari algoritme merupakan buat menolong Kamu jadi terbiasa mempraktikkan sistem perencanaan buat permasalahan tertentu. Perencanaan yang teliti bisa menanggulangi permasalahan ini sehingga Kamu bisa memaksimalkan pemecahan yang pas dikala menuntaskan permasalahan. Semacam yang Kamu amati, masalah tidak bisa dituntaskan tanpa rencana. Menekuni suatu programsangat berbeda dengan belajar bahasa pemrograman. Kala pemrograman merupakan tentang pendekatan strategis buat membongkar permasalahan, permasalahan diwakili oleh algoritma simpel yang gampang dimengerti serta dibaca buat masukan lebih lanjut ke dalam bahasa pemrograman. Pendidikan pemrograman berarti strategi pendidikan yang dinyatakan dalam wujud algoritma yang gampang dibaca serta dimengerti, membongkar permasalahan, serta menerjemahkannya ke dalam bahasa pemrograman. Hakikat dalam menekuni sesuatu program merupakan menguasai, menganalisis serta mengintegrasikan permasalahan.
\end{abstract}

Kata kunci: Algoritma, Program, Pemrograman, Bahasa, Langkah 


\section{Pendahuluan}

Algoritma menciptakan salah satu program mata kuliah yang wajib diiringi oleh mahasiswa Tata cara Informatika. Algoritma secara pendek bisa diartikan selaku langkah- langkah sistematis dan logistik dalam menuntaskan suatu kasus. Pada aplikasi hendaknya wajib efisien, menciptakan kilat, tepatman simpel. Penyajian algortima biasanya terbentuk dari flowchart, pseudocode, dan ilustrasi- ilustrasi. Algoritma biasanya ditulis ke dalam bahasa pemograman semacam C, Java, Python, PHP, dan sebagainya.

Algoritma pemrograman ialah susunanaan urutan ataupun urutan langkahlangkah logistik tertentu buat memememcahkan suatu kasus. Logis dalam bertepatan pada tersebut ditujukan bila algoritma menjajaki suatu urutan tertentu dan langkahlangkahnya pula tidak boleh diloncat. Pengertian lain dari algoritma pemrogaman ialah urutan ataupun langkah- langkah buat menuntaskan suatu kasus pada pemrograman komputer secara logistik dan sistematis. Pemograman ialah proses membuat sesuatu program dengan algortima dan basaha pemograman. Algoritma Pemograman ialah langkah- langkah yang disusun secara tertulis dan berrentetan buat menuntaskan seluruh suatu kasus pemograman komputer. Kursus Matematika Didaktik menawarkan kursus yang mencakup algoritma pemrograman. Mata kuliah ini bertujuan buat menekuni konsep bawah pemrograman lewat algoritma, langkah- langkah algoritma, serta pelaksanaan algoritma dalam sistem pemrograman. Dikala kita melaksanakan sesuatu kegiatan, kita tidak dapat lepas dari algoritma. Algoritma merupakan panduan sistematis ataupun pemecahan buat menanggulangi ataupun menanggulangi bermacam tipe permasalahan. Tiap langkah yang diambil buat membongkar sesuatu permasalahan bisa dicoba dengan metode yang berbeda, dengan fitur yang berbeda dari tiap langkah. Definisi algoritma bisa ditafsirkan selaku serangkaian langkah- langkah logis serta sistematis buat membongkar sesuatu permasalahan yang terdapat. Bagi Rinaldi Munir( 2002), algoritma terdiri dari serangkaian langkah logis yang digunakan buat membongkar permasalahan, serta langkah- langkah tersebut disusun secara sistematis. Di sisi lain, bagi Levitin( Rinaldi, 2007: 4),2 
algoritma merupakan serangkaian instruksi eksplisit buat membongkar sesuatu permasalahan, dengan beberapa input yang menciptakan output yang di idamkan. Belajar algoritma nyaris sama dengan belajar matematika. Dalam matematika, bila Kamu butuh menguasai rumus matematika terlebih dulu saat sebelum Kamu memperoleh hasil dari sesuatu permasalahan, serta bila Kamu butuh menguasai algoritma serta prosedur, Kamu wajib terlebih dulu menguasai kode tertentu yang diucap pengkodean buat melaksanakan aplikasi Kamu. Serta Kamu wajib dapat menuangkannya dengan metode yang berbeda, dengan simbol yang gampang dibaca serta dimengerti.

Algoritma mempunyai sebagian watak, antara lain: 1. Menerima input. 2. Proses entri dalam sebagian langkah. 3. 3. Tiap langkah wajib didefinisikan dengan baik, simpel serta efisien. Urutan langkah- langkahnya terbatas serta Kamu wajib menghentikan permasalahan supaya tidak terjalin. Pemrograman merupakan proses implementasi sesuatu algoritma dengan memakai bahasa yang telah terdapat dalam sistem pemrograman( Budi, 2015: 21).

Tujuan pemrograman merupakan buat bisa melaksanakan perhitungan serta tugas cocok kebutuhan dikala menulis program. Oleh sebab itu, pemrograman memerlukan keahlian algoritmik. Pemrograman berasal dari kata“ program”. Ini berarti satu setinstruksi yang terbuat buat melaksanakan guna tertentu di pc Kamu. Pemrograman merupakan aktivitas yang digunakan pc buat membuat program. Suatu program dibutuhkan supaya pc bisa berperan selaku pc. Bahasa pemrograman mempunyai sebagian ciri.

1. Siapkan tata bahasa serta ketentuan spesial dikala membuat perintah serta struktur program, deklarasi, serta juru bahasa operasional.

2. Terdapat bibliotek interupsi

3. 3 buat menerjemahkan perintah input.

Silakan pakai penerjemah. H. Juru bahasa ataupun compiler buat menerjemahkan tata bahasa pemrograman ke dalam bahasa mesin pc. Dalam pemrograman, Kamu bisa memakai bahasa yang diucap TuringLengkap buat menggambarkan seluruh perhitungan yang dicoba oleh mesin Turing. Mesin Turing mempunyai variabel integer serta operator aritmatika, statment penugasan, statment sekuensial, statment pemilihan, serta 
statment iteratif. Pernyataan yang digunakan dalam mesin Turing secara formal didefinisikan oleh konsep matematika.

\section{Metode Penelitian}

Metode Penelitian Metode yang digunakan dalam penelitian ini diambil dari buku-buku referensi dan jurnal-jurnal yang diterbitkan. Dalam penelitian ini jurnal penelitian menyebutkan teori dan konsep dasar algoritma pemrograman, metode/teknik/strategi algoritma pemrograman. Format ringkasan adalah penerapannya dalam kehidupan, bersama dengan algoritme dan bahasa yang digunakan dalam pemrograman, strukturnya, subjek penelitian, dan contoh teknik ini. Ada beberapa ketentuan untuk melakukan survei

ini.

1. Diperlukan minimal 10 referensi jurnal untuk pengambilan keputusan pertama dalam penelitian ini. Jurnal membutuhkan beberapa topik yang telah ditentukan sebelumnya. Selain itu, ini harus dipenuhi.

Yaitu, majalah dari tahun 2015.

2.Ketentuan kedua dari survei ini membutuhkan minimal dua referensi. Judul buku yang dipilih dalam referensi penelitian ini adalah "Algortma \& Pemrograman dalam Bahasa C++”, dan penulis buku ini adalah Uce Indahyanti, M.Kom dan Yunianita Rahmawati, M.Kom. Buku kedua yang berjudul "Logika dan Algoritma" ditulis oleh Ali Ridho Barakbah, S.Kom. , PhD. , Tita Karlita, S.Kom., M.Kom. Ini DanAhmad Syauqi Ahsan, S.Kom. Buku ini berisi materi tentang algoritma pemrograman dan contoh bagaimana algoritma diterapkan dalam kehidupan kita sehari-hari.

3.Keputusan ketiga dalam survei ini adalah jumlah kata minimum dalam survei ini adalah 3000 kata. Istilah algoritma berasal dari istilah "algoritma" dan mengacu pada matematikawan muslim bernama Ibnu Kharazmi yang hidup pada abad ke-19. Dalam perkembangannya, ide-idenya digunakan untuk menjelaskan dan memecahkan masalah secara logis sebagai metode algoritmik dalam proses kerja komputer matematis. Penelitian ini menjelaskan tentang definisi algoritma, konsep algoritma, notasi algoritma, fitur, properti, dan framework untuk mempelajari algoritma, serta langkahlangkah untuk mengatasi algoritma pemrograman. 
Penelitian ini juga membahas perbedaan antara algoritma dan pemrograman. Dari perbedaan tersebut, saya akan menjelaskan hubungan antara algoritma pemrograman.

\section{PEMBAHASAN}

Algoritma

Algoritma adalah sistem komputer yang memiliki perangkat otak (brainware), perangkat keras (hardware) dan perangkat lunak (software). Tanpa ketiga hal tersebut sistem komputer tidak akan berfungsi. Saat kita fokus memperhatikan Algoritma adalah suatu sistem komputer yang terdiri dari otak (brainware), perangkat keras (hardware), dan perangkat lunak (software). Tanpa ketiganya, sistem komputer tidak akan bekerja. Jika Anda fokus pada perangkat lunak komputer. Perangkat lunak ini didasarkan pada struktur dan tata bahasa (deskripsi/program) program.

Diperlukan teknik menulis, tata bahasa, langkah-langkah. Itu bisa sistematis dan logis. Sebuah masalah atau tujuan dalam proses resolusi. Membuat perangkat lunak. Nah, algoritma. Ini memainkan peran penting dalam pemrograman dan tata bahasa. Algoritma utama memiliki dua struktur dasar.

1.Gunakan sistem belajar mandiri (bahan belajar mandiri) dan simpan di komputer Anda. Instruktur dapat mampir kapan saja, di mana saja. 2. Anda dapat menggunakan komputer kapan saja untuk melihat kemajuan pembelajaran, kurikulum, skor kemajuan survei, dan topik pendidikan lainnya. Algoritma adalah serangkaian langkah logis yang digunakan untuk memecahkan masalah konfigurasi secara sistematis. Algoritme yang disebutkan dalam referensi lain adalah proses yang merupakan serangkaian langkah-langkah terintegrasi atau cara tertentu untuk memecahkan masalah nyata (WebsterDictionary). Kami juga menerapkan algoritme dalam kehidupan sehari-hari, seperti mengirim email, menginstal aplikasi, menerima pembayaran di ATM, stasiun pengisian daya, membuat kue, dan mengendarai sepeda motor. Berikut beberapa contoh algoritma dalam kehidupan sehari-hari:

Contoh 1: Mengendarai sepeda motor:

1.Mulai

2.

Masukkan

kunci

3. Boot mesin 
4. Gunakan gigi 1

5. Putar throttle grip

6. Lakukan

Contoh 7 Bersepeda 2: Kirim email:

1. Mulai

2. Tulis email (pesan baru)

4. Masukkan dan tulis email Anda alamat dan subjek penerima:

Contoh 3: Sambungkan perangkat Anda ke jaringan WLAN

1.1. Awal

2. Pilih jaringan WiFi yang tersedia .

3. Masukkan nama pengguna dan kata sandi Anda.

4. Jika tidak cocok, sistem menunjukkan bahwa koneksi gagal.

5.Koneksi internet tersedia jika diinginkan.

Properti, Properti, Bentuk Dasar, dan Cara Menulis Algoritma Menurut Donald E. Knuth, sebuah algoritma memiliki lima properti yang sangat penting. 1. Pembatasan. Algoritme harus selesai setelah beberapa langkah pemrosesan.

2. Keputusan (kepastian), semua tindakan harus ditafsirkan dengan benar. Artinya, hanya

satu.

3. Ada 0 atau lebih data input dalam input dan algoritma. 4. Saya memiliki algoritma dengan output 0 atau lebih besar. Lima. Prosedur penelitian algoritma harus efektif, tepat waktu dan berhasil. Sifat algoritma, yaitu : 1. Bahasa pemrograman tidak menggunakan simbol/tata bahasa tertentu 2. Bahasa pemrograman tidak bergantung pada apapun 3. Semua bahasa pemrograman tersedia dalam Notasi

4. Algoritma representasi dapat digunakan untuk kejadian yang diurutkan secara logis dan dapat diterapkan pada semua kejadian sehari-hari. 


\section{Notasi Algoritma}

Notasi algoritma bukanlah notasi pemrograman, melainkan notasi yang dapat digunakan sebagai notasi pemrograman. Notasi algoritmanya adalah sebagai berikut. 1. Descriptive Sentence Strand (Natural)

Algoritma deskriptif adalah algoritma yang ditulis dalam bahasa manusia seperti bahasa Indonesia atau bahasa Inggris. Simbol seperti itu cocok untuk operasi pendek, tetapi untuk simbol yang panjang, simbol seperti itu tidak efisien dan relatif sulit untuk mengubah simbol algoritma menjadi simbol bahasa pemrograman.

\subsection{Pseudo code}

Pseudocode terdiri dari kata-kata "pseudo" dan "kode". Pseudo mengacu pada imitasi, dan kode mengacu pada kode yang terkait dengan instruksi yang ditulis dalam komputer atau kode bahasa pemrograman. Kode semudigunakan untuk menggambarkan aliran logis dari suatu program dan tidak ada hubungannya dengan bahasa pemrograman.

3.

Flowchart

(bagan

alir)

Bagan alir atau flowchart adalah diagram yang menggambarkan serangkaian langkah dari awal hingga akhir suatu kegiatan atau program, dengan menggunakan simbol atau gambar tertentu dan garis alur. Simbol mewakili fungsionalitas langkah program, dan garis alur mewakili urutan simbol yang diproses. Flowchart lebih cocok digunakan daripada pseudocode. Jumlah simbol yang digunakan dalam diagram alurkecil karena lebih sederhana dan lebih mudah dipelajari. Tidak ada rumus atau tolak ukur yang mutlak untuk membuat bagan alir program, karena bagan alir merupakan gambaran dari hasil analisis masalah komputer. Oleh karena itu, hasil flowchart dapat bervariasi dari programmer ke programmer. 


\begin{tabular}{|c|c|c|}
\hline SIMBOL & NAMA & FUNGSI \\
\hline & TERMINATOR & Permulaan/akhir program \\
\hline & $\begin{array}{l}\text { GARIS ALIR } \\
\text { (FLOW LINE) }\end{array}$ & Arah aliran program \\
\hline & PREPARATION & $\begin{array}{c}\text { Proses inisialisasi/pemberian harga } \\
\text { awal }\end{array}$ \\
\hline & PROSES & $\begin{array}{c}\text { Proses perhitungan/proses pengolahan } \\
\text { data }\end{array}$ \\
\hline & $\begin{array}{l}\text { INPUT/OUTPUT } \\
\text { DATA }\end{array}$ & $\begin{array}{l}\text { Proses input/output data, parameter, } \\
\text { informasi }\end{array}$ \\
\hline & DECISION & $\begin{array}{l}\text { Perbandingan pernyataan, penyeleksian } \\
\text { data yang memberikan pilihan untuk } \\
\text { langkah selanjutnya }\end{array}$ \\
\hline & $\begin{array}{c}\text { ON PAGE } \\
\text { CONNECTOR }\end{array}$ & $\begin{array}{c}\text { Penghubung bagian-bagian flowchart } \\
\text { yang berada pada satu halaman }\end{array}$ \\
\hline & $\begin{array}{l}\text { OFF PAGE } \\
\text { CONNECTOR }\end{array}$ & $\begin{array}{l}\text { Penghubung bagian-bagian flowchart } \\
\text { yang berada pada halaman berbeda }\end{array}$ \\
\hline
\end{tabular}

Simbol - simbol Flow chart

Contoh Flow chart untuk menentukan bilangan terkecil

Gambar Flowchart Dengan Struktur Runtunan

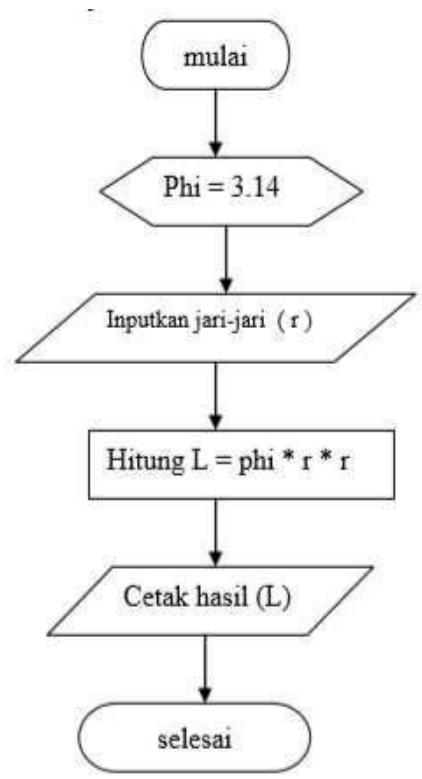


Starting with the terminal symbol 'start', the symbol for determining the starting price, phi $=3.14$, is entered in the variable $\mathrm{r}$ (radius),

Dihitung dengan ekspresi $\mathrm{L}=$ phi $* \mathrm{r} * \mathrm{r}$ dan mengeluarkan hasilnya (disimpan dalam variabel L), terminal terakhir sudah siap. Contoh berikut juga menggunakan diagram alur dari struktur sekuensial masalah menonton film di rumah.

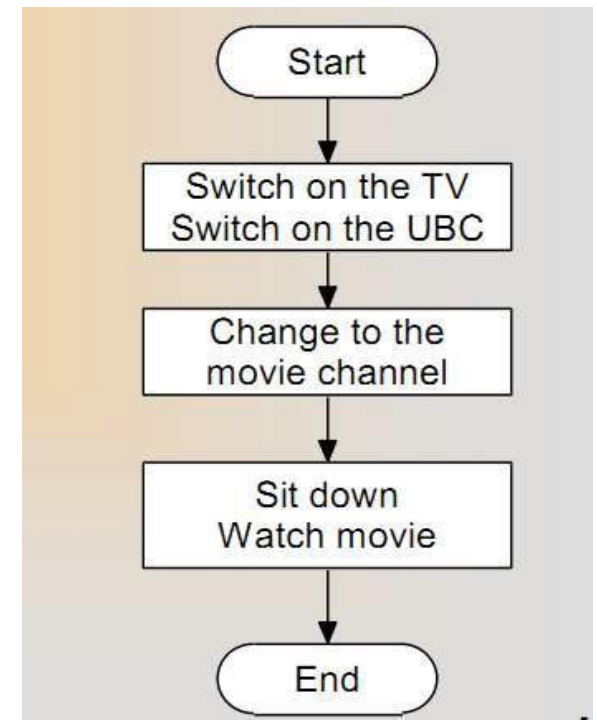

\section{Perulangan If \& Switch}

If serta switch adalah bahasa $\mathrm{C}$ yang digunakan untuk membuat penyeleksian keadaan atau percabangandalam program . Jika digunakan untuk menyeleksi suatu keadaan apakah benar atau salah. Yang setelah itu tiap-tiap-tiap keadaan diberi suatuprogram yang hendak dijalankan bila kodisi terpenuhi.

Bentuk-wujud logika logika if dipecah jadi 3 antara lain

\section{If Tunggal}

Metode penyusunan if tunngal

if (keadaan)

Kode yang hendak dijalankan bila keadaan benilai benar;

2. Jika .... Berbeda

Pada logika jika ... suatu statmen yang ditambahkan secara berbeda hendak dijalankan untuk percabangan dengan kodisi yang layak dan benar.

metode penyusunan jika ... berbeda 
Jika (keadaan)

Kode yang hendak dijalankan keadaan bernialai benar; tambahan

Kode yang hendak dijalankan keadaan bernialai salah;

3. Jika. berbeda. jika

jika...berbeda ... jika Logika also diucapkan Saat tahap digunakan untuk review menangani beberapa situasi BERBEDA di SETIAP Pemeriksaan. Dalam hal ini, instruksi If dan Differently If, masing-masing, harus dieksekusi dalam keadaan yang benar. Pada akhir Secara berbeda-beda untuk menanggulangi yang bernilai salah. metode penyusunan jika ... berbeda ... jika

(keadaan 1) Kode yang hendak dijalankan bila keadaan 1 benar-benar layak; berbeda jika (keadaan 2) Kode yang hendak dijalankan bila keadaan 2 layak; berbeda Kode yang hendak dijalankan bila keadaan 1 \& 2 layak; Saklar sebaliknyadigunakan untuk menyeleksi suatu variabel yang banyak serta sangat komplek untuk dipilih oleh If. Penggunaannya bertujuan untuk membuat meringkas penyusunan kode program serta tingkatkan kecepatan serta ketepatan program dan menyeleksi suatu variabel nilai. Tetapi keadaan pada Swich cuma bisa menyeleksi nilai tidak dapat menyeleksi keadaan semacam If.

metode penyusunan switch switch (n) case nilai1 kode yang hendak dieksekusi bila $\mathrm{n}=$ nilai1; istirahat ; kasus nilai2 kode yang hendak dieksekusi bila $\mathrm{n}=$ nilai2; istirahat ; kasus nilai3 kode yang hendak dieksekusi bila $\mathrm{n}=$ nilai3; istirahat $; \ldots$... default

Kode yang ingin dieksekusi bila tidak terdapat yang sama dengan seluruh lebel Array Array merupakan suatu variabel yang memiliki elemen dari jenis informasi yang sama. array memiliki kapasitas yang nilainya ditetapkan pada saat pembuatan menjadikan elemen atau informasi yng ditaruh diarray tersebut jumlahnya tidak boleh melebihi yang dialokasikan. Array dipecah jadi 3 ukuran

a). Array satu dimensi Array yang terdiri dari

$\mathrm{n}$ kolom, atau array satu ukuran, adalah array yang hanya terdiri dari satu indeks array . 
B). Array dua dimensi

adalah istilah arrayyang menggunakan angka dengan nomor indeks dua.

C). Array multidimensi

adalah variabel yang menyimpan kumpulan dari jenis informasi dan elemen yang sama yang dapat diakses melalui beberapa indeks atau beberapa indeks.

\section{Loop}

Sebuah lingkaran atau lingkaran adalah operasi yang berulang kali dicoba dalam batas yang ditentukan. Anda dapat menggunakan lingkaran untuk membuat kode pemrograman Anda efektif. Ada berbagai struktur kontrol seperti Dalam kasus 1. Ini adalah lingkaran yang terkandung dalam lingkaranterhitung karena jumlah iterasi yang dapat ditentukan. Metode yang menyatakan ini adalah Untuk (keadaan awal; kondisi keadaan; pernyataan) Pernyataan atau pernyataan;2.2. sementara itu adalah lingkaran yang terkandung dalam lingkaran yang tidak terhitung. Ini karena biasanya dapat digunakan berulang kali untuk sesuatu yang tidak diketahui berapa kali. Struktur sementara adalah sebagai berikut keadaan awal pernyataan ; iterasi

\section{Do While}

Perulangan Do while adalah sejenis perulangan sedangkan dan juga tergolong perulangan yang tidak terhitung. Iterasi ini adalah satu kali. Kemudian, ketika melingkarisaat pertama-tama memeriksa situasi dan kemudian melakukan iterasi, ia melakukan yang sebaliknya. Struktur dowhile adalah sebagai berikut keadaan awal penyataan; belakang; sementara (kondisi bersyarat);

\section{Struktur Dasar Algoritma}

Struktur algoritma dasar Algoritma memiliki tiga elemen dasar: urutan, seleksi, dan iterasi. Algoritma dapat membentuk tiga jenis struktur. Ketiga struktur tersebut dijelaskan di bawah ini.

Urutan pertama

Urutan memiliki satu atau lebih pernyataan.

Urutan Dari tugas ini untuk menentukan akhiran dari algoritma. 
Saat urutan penulisan berubah, begitu juga hasil akhirnya. Anda dapat melihat contoh berikut dari operasi aritmatika berikut $(4+3) * 7=49$, tetapi jika Anda mengubah urutan tindakan, output akan berbeda dari $4+(37)=25$.

2. Pilih Ada mungkin masalah yang hanya dapat diselesaikan jika itu mungkin dalam keadaan tertentu. Kondisi ini menentukan apakah instruksi itu benar atau salah. Petunjuk hanya dapat dieksekusi jika bernilai true. Di sisi lain, jika instruksinya salah, itu tidak akan dieksekusi. Contoh dalam hal ini adalah untuk menentukan bilangan genap atau ganjil sebagai berikut: Silakan masukkan bilangan bulat Bagilah suatu bilangan dengan 2 dan simpan sisa pembagiannya dalam variabel sisa Jika sisanya adalah 0 , ikuti langkah

4. Tampilan " LURUS" di layar Jika sisanya bukan nol, ikuti langkah 6 . Tampilkan "angka ganjil" di layar Telah selesai

3.

Ulangi

Salah satu kelebihan komputer adalah Anda dapat mengulang pekerjaan tanpa sepengetahuan Anda. Pengulangan adalah ketika satu tindakan atau beberapa kembar mencapai jumlah tertentu atau bertindak sesuai dengan kondisi yang diperlukan. Sebagai contoh, tampilkan karakter tertentu n kali di layar, seperti yang ditunjukkan di bawah ini.0 Menampilkan karakter di layar Tingkatkan penghitung sebanyak 1 Untuk nilai penghitung \& lt; $\mathrm{n}$, lanjutkan ke langkah 6 Ketika nilai penghitung = n selesai

\section{Belajar Pemrograman Komputer}

Definisi pemrograman komputer adalah menulis, menguji, men-debug, dan mengelola karakter pemrograman. Ada banyak bahasa pemrograman yang digunakan saat menulis kode di komputer. Oleh karena itu, tujuan pembelajaran pemrograman komputer adalah untuk menerbitkan suatu program yang dapat melakukan perhitungan sesuai dengan kebutuhan programmer tersebut. Mampu memprogram membutuhkan pengetahuan tentang keterampilan pemrograman, algoritma, logika, bahasa pemrograman, dan banyak situasi lainnya. Seperti matematika. Purnamasari (2005:2) menyatakan bahwa beberapa kriteria, seperti keterampilan pemecahan masalah dan pemrograman, 
diperlukan sebagai dasar evaluasi untuk mengidentifikasi kriteria perencanaan yang baik. Dari semua teknik pemecahan masalah standar, pendekatan top-down adalah salah satu teknik pemecahan masalah yang paling umum. Masalah kompleks jatuh ke dalam beberapa tingkat kelompok, yang merupakan subkelompok terkecil. Kemudian sesuaikan saja langkah-langkahnya, termasuk detailnya. Langkah-langkah rinci ini sering disebut sebagai algoritma. Proses masalah-ke-algoritma disebut fase pemecahan masalah, dan fase algoritma-ke-pemecahan disebut fase implementasi. Solusi untuk masalah ini adalah implementasi dari algoritma kompilasi. Berikutnya adalah standar pemrograman. Beberapa faktor membuat standar pemrograman:

\section{Deskripsi logika dan kebenaran}

2. Waktu pemrograman terpendek.

3. Kecepatan maksimum eksekusi program.

4. Hasil cetakan penggunaan memori.

Langkah-langkah dan fungsi algoritma

Prosedur adalah program independen dalam bloknya sendiri dan digunakan sebagai subprogram (bagian dari program). Ini dimulai dengan kata alternatif "program" di bagian deklarasi program. Proses ini biasanya berupa kegiatan seperti perhitungan luas, perhitungan faktorial, dan pencarian tinggi/rendah. Prosedur sering digunakan dalam program terstruktur karena alasan berikut:

1. adalah aplikasi dari konsep program modular yang berusaha untuk memecah program yang kompleks menjadi bagian-bagian yang lebih sederhana dalam bentuk program. 114444

2. Seberapa sering sesuatu diulang. Itu ditulis ke program hanya sekali dan dapat dipanggil atau digunakan kapan saja sesuai kebutuhan.

3. Buat kode program agar lebih mudah dibaca

4. Perbedaan antara fungsi dan prosedur yang dapat digunakan untuk menyembunyikan detail program adalah sebagai berikut:

1.1. Untuk fungsi, nilai kembalian disertakan dalam nama fungsi (jika parameter dilewatkan sebagai referensi dalam prosedur). 
2. Nilai kembalian disertakan dalam nama fungsi, sehingga Anda dapat menggunakan fungsi untuk menampilkan hasilnya secara langsung. Atau, Anda dapat meneruskan nilai fungsi ke pengenal variabel lain.

3.3. Anda tidak dapat menggunakan nama program secara langsung dalam program Anda, tetapi Anda dapat menggunakan parameter, termasuk nilai yang dikembalikan, secara langsung. Perbedaan antara algoritma dan pemrograman Bahasa pemrograman dan algoritma sangat erat kaitannya dengan program. Jika algoritma yang baik tidak memilih struktur data yang tepat, program akan buruk dan sebaliknya. Saat menghubungkan algoritme ke program Anda, Anda harus mengikuti aturan berikut:

1. Membuat atau membuat algoritma tidak bergantung pada bahasa. Ini berarti bahwa algoritme ditulis secara independen dari bahasa pemrograman dan komputer yang memprosesnya.

2. Catatan algoritma diterjemahkan ke dalam bahasa pemrograman

3. Semuanya bahasa pemrograman. Outputnya tetap sama karena algoritmanya sama.

\section{Penutup}

\section{Kesimpulan}

Algoritma pemrograman adalah penempatan atau urutan langkah-langkah logis tertentu yang digunakan untuk memecahkan suatu masalah. Dalam hal ini, algoritma harus mengikuti urutan tertentu dan logis untuk tidak melewatkan langkah-langkahnya. Interpretasi lain dari algoritma pemrograman adalah urutan atau langkah untuk memecahkan masalah pemrograman PC secara logis dan sistematis. Sebuah algoritma pemrograman

adalah urutan atau langkah yang secara logis dan sistematis memecahkan masalah pemrograman PC. Dalam praktiknya, algoritme dapat dibangun menggunakan beberapa sesi: algoritme bahasa alami, kodesemu, dan diagram alur.

Algoritma adalah istilah untuk "algoritma" yang berasal dari seorang matematikawan muslim bernama Ibnu Kharazmi. Dia hidup di abad ke-19. Dalam perkembangannya, ide-ide yang harus ia pecahkan secara jelas dan logis diterapkan sebagai metode algoritmik dalam matematika proses kerja komputer. 
Algoritma adalah serangkaian langkah logis untuk memecahkan masalah yang ditempatkan secara sistematis. Bisa dibilang ini adalah proses yang terintegrasi. Atau cara khusus untuk memecahkan masalah nyata. Algoritma ditempatkan secara bertahap secara tertulis, satu per satu, untuk mengakhiri masalah atau masalah. Algoritma pemrograman adalah langkah-langkah yang ditulis secara berurutan untuk memecahkan masalah yang ada dalam pemrograman komputer. Pemrograman sederhana dari algoritme adalah langkah pertama yang perlu Anda buat sebelum Anda menulis program. Masalah yang dipecahkan oleh pemrograman komputer adalah yang berhubungan dengan perhitungan matematis. Menggunakan algoritma untuk menyelesaikan masalah pemrograman memungkinkan siswa untuk lebih memahami konsep algoritma pemrograman sehingga tidak banyak melakukan kesalahan saat menulis program komputer. Pemrograman adalah proses yang digunakan untuk mengimplementasikan suatu algoritma dengan menggunakan bahasa yang sudah ada dalam sistem pemrograman (Budi, 2000: 21). Tujuan dari pemrograman adalah untuk memungkinkan Anda melakukan perhitungan dan melakukan apapun yang Anda inginkan ketika Anda menulis sebuah program. Oleh karena itu, pemrograman membutuhkan pengetahuan tentang algoritma. Kata pemrograman berasal dari kata program. Ini berarti sekumpulan instruksi yang dibuat untuk melakukan fungsi tertentu di komputer Anda. Pemrograman adalah semua aktivitas yang Anda perlukan untuk memprogram di komputer Anda. Sebuah program harus ada agar komputer berfungsi sebagai komputer. Bahasa pemrograman memiliki beberapa karakteristik. 1. Bersiaplah dengan tata bahasa dan aturan khusus saat menulis perintah, struktur program, deklarasi, dan menggunakan penerjemah.

2. Ada perpustakaan interupsi untuk menerjemahkan perintah yang dimasukkan,

3.3. Penggunaan penerjemah, yaitu juru bahasa atau compiler, untuk menerjemahkan sintaks pemrograman ke dalam bahasa mesin komputer. 


\section{Daftar Pustaka}

Ardyan, Stephanus, Mulyono, Amin Suyitno. 2017. Implementasi algoritma Dijkstra untuk mencari rute terpendek menuju objek wisata Kabupaten Gunung Kidul program Visual Basic. Jurnal Matematika FMIPA. Vo. 6, 2.

Bagus, Kadek dan Teristha Udayana. 2018. Dasar. Jurnal Bisnis dan Teknologi Politeknik. Jil. 5, No. 1.

Cheanna, Andy. 2017. Penerapan algoritma tripod pada robot hexapod menggunakan Arduino Mega128. JurnalPenelitianInformatikaPostaland. gulungan7, No.1, Hal: 3748.

Indahyanti, Uce dan Yunianita Rahmawati. 2020. Algoritma Pemrograman Dalam Bahasa C++. Jawab Timur: UMSIDA Press.

Naufal, Mohammad Farid. 2018. Analisis pembelajaran pemrograman dan teknologi pendidikan di universitas dan industri. Majalah ilmu komputer dan multimedia. Volume10, No. 2.

Retta, Allen Marga, Asnurul Isroqmi, Tika Dwwi Nopriyan .2016. Pengaruh Penerapan Algoritma Terhadap Pembelajaran Pemrograman Komputer. Jurnal Inovasi Pendidikan Matematika. Jil. 02, No. 2, Hal: 126135.

Samsudin, Indrawan dan Sri Mulyanti. 2020. Merancang sistem informasi algoritma pembelajaran dan pemrograman berbasis web pada program STMIKERSHA teknik ilmu komputer. Jurnal ilmu komputer. Jilid 5, No. 4, halaman: 521528.

Yahfizham, Kasmana Rukun, Krismadinata, Ganefri, Sukardi, WizwardiJalinus 2018. Pembelajaran pada Mata Kuliah Elektronika Tenaga: Tinjauan Pustaka. Majalah teknologi dan pelatihan kejuruan. Jilid 15, No. 2, halaman: 157. 